\title{
The Strangeness of Strangers: English Impressions of Italy in The Sixteenth Century*
}

Italy has always exercised a seductive fascination for English travellers. From the time in which Gregory the Great identified Angli with angeli to the present proliferation of packaged Cook's tours and historic Tuscan villas bearing curiously incongruous English names, the appeal of the peninsula for the inhabitants of what was once the farthest outpost of the Roman Empire has remained powerful. Just to list the English travellers to and inhabitants of Italy would read like an only slighly abbreviated Dictionary of National Biography; and of those not catalogued, a significant majority would probably have agreed with Samuel Johnson and admitted to an inferiority.

Nevertheless, this is not to say that the perceptions of Italy and the Italians have been uniformly positive. Indeed, there has always been a powerful dichotomy, a species of schizophrenia, in the English appreciation of the peninsula. On the one hand, Italy was viewed, in the opinion of one visitor in 1549, William Thomas, as "the nation which seemeth to flourish in civility most of all other at this day,"1 an opinion repeated by another English visitor a century later, John Milton, who judged Italy to be "the lodging place of humanities and of all the arts of civilisation."

On the other hand, however, Italy was equally seen as a dangerous place, a fulsome arena of murder, treachery, licentiousness and atheism. A contemporary of Thomas, Sir John Cheke, observed in 1554 that "the misery and beastliness of this country is such that for men to bear pains and travails in it is good enough," ${ }^{\prime 3}$ a vision also carried to the end of the century by the novelist Thomas Nashe, who characterised Italy as the school for "the art of epicurizing, the art of whoring, the art of poisoning, the art of sodomitry." The dramatis personae of late Elizabethan, Jacobean and Caroline tragedies reinforce this situation; from Iago to Bosola, 
the Italian personality and the disposition of the country were assumed to breed vice, treachery and lingering death.

The most common explanation for this division of opinion has been that the Reformation caused an anti-Catholic and hence an anti-Italian reaction by the Protestant English. That suggestion is manifestly incorrect. All of the gentlemen whose observations are recorded above were Protestants and some, like Thomas, Cheke and Milton, rather extreme Protestants; Nashe was an anti-Puritan Anglican. Milton, of course, served as Oliver Cromwell's secretary and Thomas was Clerk of the Privy Council under Edward VI and Jane Grey; yet both of these men saw the peninsula as a blessed land, an example to the world. Cheke, and his continuator and pupil, Roger Ascham, however, although equally advanced Protestants, saw Italy as a blight on Europe and Italians as diabolical. Religion provided much ammunition and even more emotion to the anti-Italians but the Reformation of the English church or the Roman Catholic Counter-Reformation cannot be seen as sufficient cause for this complexity of English attitudes.

What, then, is the reason for this ambiguous relationship between England and Italy in the sixteenth century? The causes are complex and do not easily sustain any dramatic or simplistic generalisations. Thus, the most effective means of investigating the question is to study the recorded impressions of English visitors to Italy during the sixteenth century within the context of their historical circumstances and their own experiences to reveal the forces at work, both positive and negative, direct and indirect. The middle years of the century will be examined most closely because it was in those years that the English appreciation of Italian culture became relatively widespread. It was then that the Elizabethan courtier became an inglese italianato, and even, on occasion, un diavolo incarnato. Also, of course, that was the period of the Reformation, the event which removed England from the spiritual orbit of Rome and the political orbit of the Catholic powers. The visions and observations of the Italian peninsula made in those years pre-disposed the images of the subsequent century in which Machiavels eagerly poisoned characters with Italian names who practised murder, incest, treachery and torture on stages identified as Italian courts. Clearly, whatever resolution to the question there might be resides in the period which initially gave rise to it.

English visitors to Italy in the early years of the sixteenth century conformed much more to the traditional, medieval patterns of travel undertaken for reasons of spiritual obligation, clerical ambition, economic gain or advanced study, usually in the 
professions. These men doubtlessly were affected by their experiences abroad and a number of them have left vivid accounts of their impressions in Italy, as George Parks has noted in his English Traveler to Italy, which discusses the years prior to $1515 .{ }^{5}$ However, with only a very few exceptions, the attitudes of these early visitors are those of men who saw themselves as part of a universal order, a singular Christian commonwealth, cemented by a common language, Latin. Indeed, between Chaucer in the fourteenth century and Sir Thomas Wyatt in the sixteenth, there was only a single translation of an Italian work directly into English, and that was a jeu d'esprit, a treatise on gambling prepared as a joke for Sir Thomas More by his friend, the Padua-trained schoolmaster, William Lyly. ${ }^{6}$ Therefore, before the late 1520 's, English visitors saw Italy in a way not very different from the package tour traveller of today. They described the ruins, the places of interest, the agricultural and cultural productions, but there is almost no sensitivity to the people, the customs, the mores or the civilisation of the Italian Renaissance, except as a distant edifice at which to marvel briefly and then move on. These men saw Italy as part of a continuing Catholic, Roman universal polity; their primary interests were in the manifestations and monuments of that universal order, for it was that still living tradition which had attracted them to the peninsula in the first place, since Italy remained a very important locus in that vision. All roads still led to Rome.

The events of the Reformation necessarily altered these traditions, although not in the ways most commonly believed. England and Italy actually grew closer in some respects because of the divorce of Henry VIII. During the 1529 canvassing of the continental universities to secure acceptable opinions on the invalidity of the King's marriage to Catherine of Aragon, the prestigious universities of Italy had a prominent place. To ensure a favourable judgement from Rome, English delegations travelled continuously to and from the Curia; and, in turn, a number of high Italian ecclesiastics resided in England. Even after the break with Rome this intimacy progressed. Archbishop Cranmer had great sympathy for the theology of the abortive Italian Reformation and brought a number of learned, usually humanistically trained, Reformers to England to help preside over the reconstitution of the English church. Bernardino Ochino, Pietro Martire Vermigli, Emmanuelle Tremelli and Pietro Bizzarri enjoyed the highest respect in the universities, in the church and at court. They disseminated from these lofty places not only a new theology but a dedication to good letters and to the Italian civilisation which they carried with them as important pieces of their intellectual baggage. 
Finally, the young, humanistically trained scholars who had left England to study the New Learning in the secular atmosphere of the University of Padua returned home, often at Thomas Cromwell's bidding, to fill the Tudor bureaucracy and become pamphleteers in the escalating propaganda war against the radicals on the left and the conservatives on the right. Cromwell, who himself had lived in Italy as a young man, saw the advantage of utilising the services of such well educated laymen, skilled in argument and rhetoric, to help establish the Henrician order. And, because of these men, such as Richard Morison and Thomas Starkey, the familiarity with and access to Italian civilisation spread down from the highest pinnacles of the court to the educated gentry and mercantile classes who saw an Italian humanist education as a certain social escalator. Italy, then, during the 1530's and 1540's was not the home of the Anti-Christ as much as it was the graduate school of humanism and the vita civile, providing, especially at the great Venetian University of Padua, a secular education in litterae humaniores then available nowhere else.?

What had begun as the aristocratic affectations of a handful of poet-courtiers gathered around Sir Thomas Wyatt and the Earl of Surrey early in Henry's reign had become by its end a substantial movement of dedicated humanists, Italianate insofar as most of them had studied in Italy, knew the language and the culture or had great respect for the learned riformatori who had recently joined their own theologians in an attempt to establish a Church with a particularly English, doctrinely eclectic, character.

Therefore, neither the advancement of the Reformation in England nor even the establishment of the Roman Inquisition in 1542 and the Venetian Tre savi sopra eresia in 1547 curtailed the flow of English travellers to Italy during the middle years of the century. What these events did accomplish, however, was a change in the character of the travellers. First, they were virtually all laymen, the justification for clerical visits to Rome now having evaporated; second, they were gentlemen of good birth who saw the advantages of an Italian education in furthering their careers in the royal service; third, they were increasingly men of culture and sophistication who had enjoyed at least some university training before going to the peninsula. These men wanted not only the professional advantages of a humanistic education - which, after all, had become available in England by the 1540's - but also the patina of culture, manners and social finesse which had made the image of the cortegiano a model of aristocratic behaviour throughout Europe, but especially in England. ${ }^{8}$

Moreover, besides changing the social profile of the English 
visitors, the events of the Reformation changed their points of view, their assumptions about the place. The traditional attitude of seeing Italy as but another, albeit the most important, place in the universal order of the Respublica Christiana, strongly identified with its Roman antecedents, had necessarily passed forever. The unity of the Church and of the idea of Empire had been shattered irrevocably. The travellers saw themselves as Englishmen much more than previously, members of a national church and subjects of a national imperium ruled by a King who enjoyed the authority of imperator in suo regno. Because of this transformation in perspective on the part of the English visitors, the Italians underwent a concomitant change in the perception of these foreigners. The Italians were suddenly a totally different people with local, national customs and an alien culture. Differences rather than similarities were stressed increasingly: they became an exotic, peculiar race. Because the observer had changed, so did the observed. And it was this metamorphosis on the part of English visitors which brought about their discovery of Italy as an exotic land, full of strange and curious people so different from themselves, peculiarities which the travellers sought to record, analyse and understand, if they could. It was thus that the perceptions of the Italian character which ultimately led to the dual strains of Italophilia and Italophobia were born.

What, then, is important to stress is that the English were for the first time looking at Italians as a totally distinct nationality in its own unusual habitat, rather than as but another branch of the universality and brotherhood of Christian, Latin civilisation. The Italians had not really been transformed, it was the English who had, and as events - which often had little to do with Italy at all influenced their continental policies, their impressions of the peninsula changed correspondingly, usually for the worse.

Nevertheless, if these two strains run concurrently throughout the second half of the sixteenth century, the time during which Englishmen truly became intimate with the peninsula as the locus of a contemporary civilisation, and if, as has been shown by George Parks, the English impression of Italy manifested in literature declined into a caricature of lascivious vice by the end of the century and throughout much of the next, ${ }^{9}$ how can the existence of a new class of informed English visitors, progenitors of the grand tourist of the eighteenth century, explicate the division? Quite simply, I think the answer is that not every traveller liked what he saw, once he took the trouble and had the faculties to understand the society and culture of late Renaissance Italy. Because these men were searching for a deeper understanding of 
Italian civilisation, they looked behind the brilliant façades and classical survivals into the character of the people. For most English visitors, the experience was illuminating, meaningful and positive, providing the foundation for the Italianate fashion of the reign of Elizabeth; but for a vocal and literarily influential minority the result was a severe attack of culture shock, a shock too powerful to be born with equanimity by an insular mind.

Let us return to the specific examples of Englishmen who knew or actually visited Italy in the third quarter of the century and left their impressions of that nation. The most significant of these travellers, and the one who did more than any other before Thomas Hoby's translation of Castiglione appeared to make Italy a familiar place in the English intellectual geography, was William Thomas. Thomas went to Italy initially as a felenious fugitive, having stolen a large sum of money from his noble employer, fleeing with it to the continent. ${ }^{10}$ However, Thomas made restitution and was forgiven, although he thought it prudent to remain abroad, an exile he spent almost altogether in Italy.

The fruits of his sojourn on the peninsula were two books which for the first time made Italy and the Italian language easily available to the literate Englishman. In 1549 appeared Thomas' History of Italy and in 1550 his Italian Grammar, both pioneer works which spread the fashion of things Italian from the courtly circles still excited by Wyatt's translations of Petrarch and Aretino of twenty years before. Besides the testimony of his books, Thomas' opinions and personal predilections must have favourably disposed a number of English gentlemen to view Italy as the home of a vital, attractive, contemporary civilisation. For example, Thomas wrote of Italian gentlemen:

In manners and conditions they are no less agreeable than in their speech: so honorable, so courteous, so prudent and so grave withal that it should seem each one of them to have had a princely bringing up: to his superior obedient, to his equal humble, and to his inferior gentle and courteous; amiable to a stranger and desirous with courtesy to win his love. ${ }^{11}$

For Thomas, Italian gentlemen were such that "none other nation is like them in majesty." ${ }^{\prime 2}$ His praise is warm and sincere, his appreciation of all aspects of the nation, both ancient and contemporary, deep and well considered.

Without doubt, Thomas' books exerted a powerful influence on his fellow courtiers. Among his close associates was Sir John Cheke, the Cambridge scholar. If Thomas was the favourite companion of the young King Edward VI, Cheke was his respected tutor. Thomas was Clerk of Northumberland's Council; Cheke was 
a member of it, rising at the end of the reign and during the nine day wonder of the next to the position of Secretary of State. These men worked closely together of necessity and shared the same religious affinities for very advanced Protestantism, a confessional allegiance which took Thomas to the block and Cheke to the Tower after the victory of Mary Tudor. ${ }^{13}$

When released by Mary in 1554, Cheke had little choice but to leave England, and his refuge during the first half of the Marian diaspora was Italy. He explained his motives for this decision to his Catholic successor, Sir William Petre, stating that he "intended to learn not only the Italian language, which he despaired not of, but also philosophically to course over the civil law; not seeking perfection, which requires a man's life, but avoiding the extremities of ignorance, and learning to give aim like a shooter."14 In short, Cheke had been attracted to Italy by the reputation of its universities, in this case Padua, where he ultimately settled, and by a perception on his part that some greater familiarity with the Italian language would be of some service.

Obviously, Cheke's choice of Italy was in part conditioned by his close association with Thomas, the leading Italophile of Edward's court. However, it was reinforced by his relations with Italian residents in England with whom he had been intimate. That curious astrologer and brilliant mathematician, Girolamo Cardano, who had once, he swears, been rector of the studio di Padova, ${ }^{15}$ had lodged with Cheke during a trip to London in which he had cast the horoscopes of the entire Edwardian court, including that of his special friend, Cheke. ${ }^{16}$ At Cambridge, it had been Cheke, functioning as a royal visitor, who had secured a fellowship for Pietro Bizzarri at his own College, St. John's, despite the Italian's uncertain academic qualifications. ${ }^{17}$ He knew both Peter Martyr and Tremelli quite well and must have at least enjoyed the acquaintance of Ochino. ${ }^{18}$ Thus, Italy was not a totally unknown place to Cheke because of his close connections with men of that nation while in England; and consequently, it was with high expectations that he journeyed south, in the company of the other great italianato of Henrician and Edwardian England, his friend, associate and fellow Protestant, Sir Richard Morison, the Padua trained civil lawyer who had adapted Machiavelli for the King's use during the pamphlet wars of the 1530's and 40's and who had utilised his knowledge of Roman law to argue for the King's right to dispose of the visible church, at least in England, acting legibus solutus. ${ }^{19}$ Clearly, Cheke expected much of his Italian voyage; instead, he encountered misery and his own narrow mindedness which turned his visit into a disaster. 
On reaching Padua, Cheke appeared pleased enough, describing the city as "fair and quiet" in his first letter from there, written early in July $1554 .{ }^{20}$ However, just two weeks later, on 22 July, Cheke was writing to Petre, complaining about the place and the people:

I am here in a country much esteemed in opinion, indeed not such as a man would have guessed it, I am yet unskilful thereof and therefore cannot judge certainly without rashness, else to judge at the first sight I would say that neither for private order, nor yet common behaviour it is anything to our own barbarous supposed country. Courtesans in honour, haunting of evil houses noble, breaking of marriage a sport, murder in a gentleman magnaminity, robbery, finess if it be clean conveyed, for the spying is judged the fault and not the stealing, religion to be best that best agreeth with Aristotle's De anima, the common tennant though not in kind of tennancy, marvellously kept bare, the gentleman nevertheless yet barer that keepeth him so; in speech cautious, in deed scarce, more liberal in asking than in giving. They say the farther we go into Italy, the worse. ... . ${ }^{21}$

Cheke did try to pass his time profitably. Besides reading Greek with Thomas Wilson, he lived comfortably at Padua where he shared a house (after 2 November) with Hoby and another Englishman, Sir Thomas Wrothe, and together they determined to "spend their time as honestly and as dutifully as they can and pass away those cares that might grieve the absent." ${ }^{22}$ However, he still complained to his wife that "the misery and beastliness of this country is such that for men to bear pains and travails in it is good enough but otherwise not for the English and especially those who knoweth what good bringing up meaneth." ${ }^{23}$ Here was probably Cheke's greatest complaint about Italy: the Italians were not English and refused to behave as if they were. It was as though his views on the need to maintain the purity of the English language had been projected into his life as a whole. Cheke again wrote to his wife from outside Venice before he took up his "womanly quarters ${ }^{\prime 24}$ at Padua:

your unhapp in this thing [his fall and exile] is happy that it is not troubled with the strangeness of strangers; which thing next to an evil Religion, is to my Nature most odious, and yet I may say for myself if any Englishman of longtime have been of strangers and, learned, much made of, I have had my part thereof, being honoured for many things which they know me not think to be in me.

Divert your next letters to Venice unto me, whither me think I go as Paul, warned, went to Jerusalem. ${ }^{25}$

Therefore, even if Cheke had lived longer after his return to 
England, he would never have become a proponent of Italian culture. It is significant that his preface to Thomas Hoby's translation of $I l$ Cortegiano concerns itself not at all with the contents of the book but only with his own preoccupation with unadulterated English. ${ }^{26}$ Despite his wide learning and dedication to classical scholarship, Cheke's essential attitude looks back to John Skelton rather than forward to John Harington.

Cheke's disciple, Roger Ascham, was either totally influenced by his teacher's thinking regarding Italy or independently shared the extremity of those views. In The Scholemaster (1570), Ascham rails against the Italian vogue. He confesses that he was "once in Italie myself [as Sir Richard Morison's secretary in 1551]: but I thanke God, my abode there was but ix dayes: And yet I saw in that little tyme, in one Citie [Venice] more libertie to sinne, than ever I heard tell of in our noble Citie of London in ix yeare. ${ }^{127}$

Indeed, Ascham's vituperation against Italy, Italian manners and Italian culture help animate the rather dulling length of The Scholemaster, produced almost twenty years after he had returned from the peninsula. Let the following, characteristic passage suffice:

And yet ten Morte Arthures do not the tenth part so much harme, as one of these bookes made in Italie and translated in England. They open, not fond and common wayes to vice, but such sutle, cunnyng, new and diverse shiftes, to cary yong willes to vanitie and yong wittes to mischief, to teach old bawdes new schole poyntes, as the simple head of an English man is not hable to invent, nor ever was hard of in England before, yea when papistrie overflowed all. Suffer these bookes to be read, and they shall soone displace all bookes of godly learnyng. For they, carying the will to vanitie and marryng good maners, shall easily corrupt the mynde with ill opinions and false judgement in doctrine: first, to thinke ill of all trewe Religion, and at last to thinke nothyng of God hym selfe, one speciall pointe that is to be learned in Italie and Italian bookes. . . .

That Italian, that first invented the Italian Proverbe against our English men Italianated, ment no more their vanitie in living, than their lewd opinion in Religion: For in calling them Deviles he carieth them clene from God: and yet he carieth them no farder, than they willinglie go themselves, that is, where they may freely say their mindes, to open contempe of God and all godliness, both in living and doctrine.$^{28}$

This invective was continued by Ascham's contemporary, William Harrison, whose description of England was published in Hollinshed's Chronicles in 1577 and thereafter. The popularity of the Chronicles, together with the dissemination of Ascham's treatise, did little to reinforce the positive opinions of Italy published by Thomas at the middle of the century. Harrison, in his discussion of universities wrote: 
One thing only I mislike in them [English students], and that is their usual going into Italy, from whence very few without special grace do return good men, whatsoever they pretend of conference or practice, chiefly the physicians - so much also may be inferred of lawyers - who under pretence of seeking foreign simples do oftentimes learn the framing of such compositions as were better unknown than practised, as I have heard often alleged, and therefore it is most true what Dr. Turner said: "Italy is not to be seen without a guide, that is, without special grace given from God, because of the licentious and corrupt behaviour of the people. ${ }^{29}$

Evidently, the dictum of Sir William Cecil - who was Cheke's brother-in-law and Ascham's fellow student - to suffer not thy sons to cross the $\mathrm{Alps}^{30}$ had a legitimate history, a history ever building with the passage of the century.

To introduce Cecil's opinions leads to the rehearsal of a curious comparison between the people and countries of Italy and Germany sent to that gentleman in 1567 by one Edward Moorecroft, clearly another anti-Italian traveller but one without the high profile and national stature of Cheke, Ascham and Harrison. ${ }^{31}$ The significance of Moorecroft's attitudes is thus in its proof that influential writers such as those named above were not engaging in any kind of literary convention of Italophobia in their works. Rather, given the evidence of Moorecroft's letter, they appear to have been recording a relatively widespread prejudice manifested by English observers from at least the generation of Cheke.

Moorecroft's actual letter deserves some mention. He writes:

Every country has its fashion of vice: As . . the Italians in whoring, that I say no worse of them, every which vice with every of these are counted small or no offences, because they are after the fashion (as great hose be with us) and according to the custome of the country ... [I] will never prefer the painted formality of the Italians to the German's integrity and tasting the cheese potage, cheese puddings and cheese tarts of Italy will not mislike the sup or brose of Germany. None shall like Italy unless he be Italizate [sic], and the proverb says Anglus italizatus demon incarnatus, and so say the French and Germans of their countrymen. . . The hills are woodless, the sea fishless, the women shameless and the men graceless. ....32

How far we are from William Thomas' encomium of the Italian nation! Nevertheless, although the intent is manifestly completely opposed to Thomas', there remains clear allusions to or echoes of Thomas' esteem in such censures. The implication is that Moorecroft and Cheke before him knew Thomas' book and in fact probably used it as a guide during their travels. Thus, not even the most strident anti-Italian could escape its cadences or focus. Even though Thomas' praises have been turned into vituperation, the 
components of the Italian landscape and character remain fixed for English visitors because his inspired vision of Italy had been canonised in his book. Indeed, this suggestion is reinforced by the survival of the travel journal of an anonymous English priest who journeyed to Italy with the party of Lord Montague and the Bishop of Ely sent to carry Queen Mary's obedience to the pope in $1555 .{ }^{33}$ This diary is a very traditional account of the marvels - both religious and historical - principal personages and places and topography. The writer conformed to the Medieval profile of English traveller: a Roman Catholic priest who still saw Italy as did his antecedents, as part of the universal world order of European Christianity. There is no discussion of the national particularisms and peculiarities of the Italians; what interests the observer most is the sacred relics and exotic animals kept on view in the cities through which he passes. Nevertheless, although in every way dissimilar from the italianati described by Ascham and hardly a sophisticated traveller, this anonymous priest decides against discussing entire categories of landmarks - including the classical monuments of Rome - because they were included in Thomas' book, a text he assumes his readers would know. He concludes: "To write anything of the antiquities of Rome, I thought it needless, considering that they are truly and notably set forth in William Thomas' on the Description of Italy. ${ }^{\prime \prime 34}$

Therefore, one aspect of the duality of the English attitude to Italy can certainly be traced to the continued influence which Thomas' book had on subsequent travellers. Although these later visitors might not have shared Thomas' laudatory vision of the peninsula, they could not escape the contours which his great book gave to their intellectual maps. It is for this reason that the opinions of Cheke and Ascham often appear reminiscent of or obliquely allude to Thomas, but in mirror image. Because they discussed the same elements from opposing perspectives the English impressions of Italy developed in parallel, as positive and negative reflections of the same subject.

What, however, of the orthodox disciples of Thomas? Who were they and how did they see the peninsula, these inglesi italianati so disparaged by Cheke, Ascham, Harrison and Moorecroft? The first and most interesting observation is that the italianati were often identical in religion, social status, education and career with the anti-Italians, and, in fact, were often associated and friendly with them. Admittedly, there were some Italophiles of the highest birth, such as the Earl of Bedford and Sir John Harington, cousin of Queen Elizabeth and translator of Ariosto. But, as with the Italophobes, the majority of these preceptors of Italian culture, the 
apologists for the peninsula, tended to be middling gentlemen who through ability, education and connections were on their way up, often aided by their Italian experiences, especially under Elizabeth who was something of an italianata herself, although she had never seen the continent.

Of all the mid-century italianati, the most attractive and by far the most influential was Sir Thomas Hoby, the translator of Castiglione.$^{35}$ Hoby spent many years as a student and an exile in Italy on two occasions, first from 1548-1550, and again from 1554-5. During his first visit he not only studied at the University of Padua but made an exhaustive grand tour of the peninsula which ultimately took him down to the tip of Sicily. Indeed, his rationale for taking this then unusual last step indicates the extent of his interest in Italy and his desire to grow closer to its people and avoid his English fellow travellers ${ }^{36}$ He wrote in his journal that he went to Sicily "both to have a sight of the country and also to absent myself for a while out of Englishmen's company for the tongue's sake. ${ }^{\prime \prime 37}$ Cheke would hardly have done that.

Hoby was duly rewarded for his efforts. The local inhabitants provided him with every courtesy, giving him shelter, entertainment and useful advice when in need. ${ }^{36} \mathrm{His}$ opinions of the people of Italy reveal a familiarity with all aspects of life in that country as well as with its diversity - a fact noted, significantly by all travellers who notwithstanding generalise about the Italians as a singular race. Here is Hoby's description of Siena: "The people are much given to entertain strangers gently. Most of the women are well learned and write excellently well both in prose and verse." ${ }^{39}$ There are no courtesans in honour there, apparently. Equally, unlike Cheke's "womanly quarters," Hoby finds "fair chambers and pleasant rooms." 40 Moreover, almost every page is filled with appreciative descriptions of the skill and industry of the Italians, the commodities produced and the antiquities preserved. Consequently, Hoby's decision to translate Castiglione during his second visit to Italy was not an enterprise of idleness: it was a tribute to a society and a civilisation he knew well and admired greatly.

Another celebrated Italophile was Francis Russell, Second Earl of Bedford. While a student at Cambridge - at about the same time Hoby was in residence, that is, during the humanistic hegemony of Cheke and Ascham - Russell was converted to advanced Protestantism; he was also infected with Italophilia, carrying down with him as his personal secretary Pietro Bizzarri, who preferred service in an aristocratic household to the academic life ${ }^{41}$ Like Cheke and Thomas, both of whom he knew intimately, he was implicated in the plots and rebellions against Queen Mary and, like Cheke, left 
England in 1554 for Italy, reaching Padua in June of $1555 .{ }^{42}$ Thereafter, he journeyed throughout the peninsula as far as Naples, making use of his rank to visit ruling princes, in addition to seeing the sights.

Like Hoby, whom he encountered in Padua, and unlike Cheke, Bedford loved the country. His correspondence from the peninsula is not very revealing, except for one enthusiastic letter to Cecil (ironically) who had been charged with the care of the Earl's property in England and hence was his most regular contact there. Bedford wrote from Ferrara on 24 March 1556 that

[he] has returned here from Rome and Naples. The latter, to his mind, is one of the fairest in Italy, having great commodities by the sea; the buildings are very fair and the country is so fruitful as he has not seen the like. Rome is beautified through the pope's and cardinals' palaces, whereof there is a number passing fair; the antiquities are so many and so worthy to be seen that no small time will suffice to note them all, nor his capacity reach to bear them all away; but such as his wits will serve he shall make Cecil partaker of them at his coming home. ${ }^{43}$

On his return, Bedford, despite his extreme Protestantism and his later support of the Puritans in Parliament remained something of an italianato. His library, for example, contained twelve Italian books, reflecting his affection for that country. Among those Italian works was his former retainer's Historia di Pietro Bizzarri della guerra fatta in Ungheria (1569), dedicated to him. Also, there were Italian translations of the classics, religious texts and, interestingly, two editions of Guicciardini, as well as Pietro Ubaldini's Vita di Carlo Magno, the first Italian book published in England (1580); and he owned two copies of Tasso's works, including his letters. ${ }^{44}$ His italophilia subsequently served him well in his diplomatic assignments, as witnessed by his performance as Elizabeth's ambassador to France, during which it was remarked that "the Earl hath the Italian tongue very well and the Queen Mother (Catherine de' Medici) hath pleasure in her own tongue." ${ }^{\prime 45}$ Evidently, Bedford, like most of the other italianati of the middle years of the century continued to promote and advertise his appreciation and knowledge of Italy, despite the growing alienation from the delights of the peninsula. Both perspectives of the schizophrenic English attitude towards Italy had their champions and their influential disciples.

In conclusion, then, let us return to the original question of this mutually exclusive duality in the impressions of Italy exhibited by Englishmen after about 1550. In essence, I have argued that the divergent opinions developed because the Reformation caused 
English visitors not to distrust Catholic Italy as much as to judge its civilisation and its people as detached observers, divorced from the universal absolutes of Church and classical antiquity. Some observers found the contemporary Italy of the sixteenth century attractive and worth promoting at home; others found it uncongenial, unwholesome, unEnglish: these spent the remainder of their lives deprecating the peninsula. In short, I am suggesting that the division ultimately came down to a matter of personal taste, perhaps occasioned by particular circumstances, such as the bitterness of exile and poverty in Cheke's case, as well as the effects of the almost fatal illness which he suffered there, ${ }^{46}$ or, the pleasures of sympathetic, polished, aristocratic company and entertainment, elements so significant in both Hoby's and Bedford's accounts of their visits.

Nevertheless, as has been so often observed, the popular, at least literary, characterisation of Italy and Italians declined continuously throughout the second half of the century and throughout the first half of the next. Was it that the Chekes, Aschams, Harrisons and Moorecrofts had more literary influence than the Thomases, Hobys or Bedfords, or later, than the Haringtons or Miltons? To a degree, the answer must be yes, at least for those writers of the sixteenth century. Ascham's Scholemaste and Hollinshed's Chronicles influenced far more Englishmen than even Hoby's Courtier; and, what is more important, the former books affected different types of Englishmen. From the beginning - indeed, from the very beginnings with Wyatt and Surrey - the Italianisms of the inglesi italianati had been closely associated with the court, with the aristocratic classes. Despite the social origins of Hoby and Thomas, they were seen as what they, in fact, were - courtiers; and it was to such as they that the Italian fashion was most socially and even professionally useful, especially at the court of a Queen who enjoyed nothing more than speaking Italian to visitors from that nation herself.

On the other hand, writers like Cheke and Ascham, despite their intimate connections with the court, were perceived, again correctly, as teachers, scholars, publicists and patriots. Cheke's literary productions consist almost altogether of translations from Greek, with a single hortatory treatise on the need for all Englishmen to obey their King and follow his reformed religion. ${ }^{47}$ Similarly, Ascham, besided the Scholemaster, was the author of a book on the particularly English sport of archery, the Toxophilus. Such books, when seen with Harrison's immensely popular and influential contributions to Hollinshed's Chronicles, spoke directly to the groups 
which were increasing in wealth, power and national prestige: the lesser and middle gentry and the urban mercantile classes.

Moreover, the negative impressions of Italy and her people caricatured by Ascham received ever more corroboration by the external political events of the first decades of Elizabeth's reign. In 1570 the pope excommunicated the Queen and called for her deposition by her subjects and by the Catholic powers. Probably more than any other single event this deposition of Elizabeth alienated a great number of patriotic Englishmen from Italy and served to re-establish the connection between Italy and the AntiChrist which the personalities of the 1530's and 1540's had managed to disrupt. Memories of the Marian reaction and of her Archbishop and cousin, Cardinal Pole, already dramatically revived by the publication of Foxe's Acts and Monuments seven years before, returned again altered, unjustly, by the passage of time and the change in the continental situation. And, because of these largely political circumstances, the resentment felt by patriotic Englishmen was focussed on Italy. The best example of this comes from Archbishop Parker's De antiquitate Britannicae ecclesiae (1572) which characterised Mary's unfortunate cousin, Reginald Pole, thus:

When he had remained there [i.e. Italy] for some months in safety in the very lap and bosom of the pope himself, he emerged infatuated and changed, as if he had drunk the cup of Circe, from an Englishman to an Italian, from a Christian to a papist . . .a great and monstrous metamorphosis contrary to both human and divine nature ... That simplicity which I think had been in the Englishman originally proper and ingenuous now acquired in the daily contact with the people of Rome their craftiness, still retaining the exterior and feigned appearance of an honest nature, but concealing deep within the heart the cultivated vice of deceit and fraud. ${ }^{48}$

With Parker's analysis of Pole, we are obviously approaching Iago.

Furthermore, it must be remembered that the Queen's deposition and the memory of Pole as un diavolo incarnato associated with the martyrdoms of Mary's reign all took place within the hysterical atmosphere occasioned by the discovery of the Ridolfi plot against the Queen. In 1569 and again in 1570 a Florentine banker with the highest connections, Roberto Ridolfi, plotted with the papacy, France and Spain, and powerful English Catholics, such as the Duke of Norfolk, to raise a rebellion against Queen Elizabeth and arrange for the reception of a foreign army into England which would execute the pope's deposition and replace the heretic Elizabeth with the more orthodox Mary Queen of Scots. Because of 
the widespread nature of the plot, the implication of some of England's greatest houses, and the closeness of many of the cospirators, including Ridolfi, to the court, the xenophobia just beneath the surface of the English character emerged, disguised as patriotism.

All that Cheke, Ascham, Harrison and their disciples had ever written or believed about Italy appeared to have been proved. The vile caricature of the deceitful Italian of the later Elizabethan and Jacobean stage seemed justly exemplified in Ridolfi, Pope Pius V, and through malicious hindsight, Reginald Pole. Events had shown the Italophobes right, while oniy the superficialities of fashion and the appeal of art had given any support to the views of the italianati.

In the short space of twenty years between the publication of Thomas' History and the crises of 1570 , the general impression of Italy among Englishmen changed along those lines laid down by the most vituperative of the Italophobes, Cheke and Ascham. Gentlemen may have continued to read Hoby's Courtier, and some may have even travelled to the peninsula, in spite of the warnings to avoid the place; ${ }^{49}$ however, the positive image of Italy in the English consciousness had been overwhelmed by the negative and would remain the recessive strain until the fears of Roman Catholicism, external invasion and internal insurrection were calmed.

Thus, again, it was the English who had fundamentally changed and it was the political context of Europe which had shifted. Ridolfi, to be sure, was an Italian, as was the pope; and the Jesuits who ministered to the English recusants with such courage and resourcefulness obyed instructions from Rome. Also the pressure of Counter-Reformation diplomacy meant that no Venetian ambassador resided at the court of Elizabeth ${ }^{50}$ and that for the first time the academic and religious freedom of the University of Padua was restricted through the imposition of an oath of orthodoxy. ${ }^{51}$ However, these things were manifestations of European politics in an age which saw confessional allegiance as a critical element in international affairs; they in no way represented a fundamental transformation in the character of the Italian people.

Consequently, the figures in the plays of the English theatre and the opinions of the English novelits, such as Nashe, indicate much more about the English than about the Italians. A number of polished, cultivated italianati continued to honour "the lodging place of humanitas and all the arts of civilisation," but their message was overshadowed by the opposite, negative perception which, because of its closer identification with the social and political 
circumstances of England in the reign of Elizabeth, came to dominate the popular and the literary imagination. Italy, then, through no fault of its own became the breeding ground of treachery and vice, but, in deference to the sensibilities of the remaining inglesi italianati, a place possessed of the fatal charms of Circe, intoxicating simple Englishmen with its beauty, changing them not merely into beasts but into incarnations of the devil himself.

\section{University of Toronto}

\section{NOTES}

*A version of this paper was delivered in the Italian Lecture Series, St. Michael's College, University of Toronto, 7 Feb. 1980.

1 William Thomas, The History of Italy, ed. G. B. Parks (lthaca, 1963), p.3.

2 John Milton, Defensio secunda, quoted in G. B. Parks, "The Decline and Fall of the English Admiration of Italy," Huntington Library Quarterly, 32 (1969), 341.

3 British Library, Additional MSS. 46367, F.11r.

4 Thomas Nashe, The Unfortunate Traveller, in Elizabethan Fiction, ed. R. Ashley and E. Mosely (New York, 1966), p.284. Nashe continues by observing: "It is now a privy note amongs the better sort of men, when they would set a singular mark or brand on a notorious villain, to say, he hath been in Italy."

5 G. B. Parks, The English Traveler to Italy (Roma, 1954).

6 William Lyly translated II libro delle sorte for More in 1474. The manuscripts, however, seems to have had limited circulation and cannot be said to have begun a renewed interest in Italian vernacular literature. Lyly's translation was essentially a private undertaking for a single individual.

7 See W. G. Zeeveld, Foundations of Tudor Policy (Cambridge, 1948).

8 There were, for example, ten various editions of Castiglione's Courtier printed in England during the sixteenth and early seventeenth centuries. See S.T.C. 477887. Also, see my "English Students at Padua, 1521-1558," in Proceedings of the PMR Conference, forthcoming. Even Nashe noted the courtly skills of the Italians: residence in Italy "Maketh a man an excellent courtier, a curious carpetknight ...,"The Unfortunate Traveller, 284.

9 See Parks, "Decline."

10 D.N.B., 56, 193, "William Thomas."

11 Thomas, p.12

12 Thomas, p.11

13 Christina Garrett, The Marian Exiles (Cambridge, 1938), p.115.

14 Calendar of State Papers, Foreign, Mary, 112.

15 Girolamo Cardano, The Book of My Life, ed. J. Stonor (New York, 1962), p.13. The date for this alleged rectorship was 1526.

16 Cardano, p.63. Also see Cardano's collected horoscopes of the Edwardian court, including Cheke's, in Hieronymi Cardani Mediolanensis Opera Omnia (Lugduni, 1663), especially Genitura IV, Vol.5, 512-3.

17 M. Firpo, Pietro Bizzarri, esule italiano del Cinquecento (Torino, 1971), p.25.

18 Cambridge University Library, MS Mm. 5. 41 no. 12, a letter of Cheke's to Peter Martyr, 10 March 1551. See also, B. L. Landsdowne MSS 980. 163, a letter from Martyr to Bullinger in which the kidnapping of Cheke is described.

19 See Richard Morison, A Remedy for Sedition (London, 1536), S.T.C. 20877.

20 Calendar of State Papers, Foreign, Mary, 112.

21 Public Records Office, SP 69/4 no. 240, 22 July 1554

22 British Library, Additional MSS 46367, f.11 r. 
23 Ibid.

24 Ibid.

25 Ibid., f.11v.

26 J. Hebel, H. Hudson, et al. eds., Tudor Poetry and Prose (New York, 1953), p.680.

27 R. Ascham, The Scholemaster, ed. J. B. Mayor (London, 1863), p. 82.

28 Ascham, p.85

29 William Harrison, "A Description of England," in Hollinshed's Chronicles (1577), in Chronicle and Romance, ed. C. W. Eliot (New York, 1910), pp.398-9. See also p. 235 .

30 When Cecil wished to send his son, Thomas (Cheke's nephew), out of England to be educated in civil law and in the French and Italian tongues, he preferred to send him to France because the state of religion was better there. See Calendar of State Papers, Foreign, Elizabeth, IV, 104-5, 8 May 1561. Cf. G. Parks, "The First Italianate Englishmen," Studies in the Renaissance, \$ (1961), 206-7.

31 Calendar of State Papers, Foreign, Elizabeth, VIII, no. 879, 1 January 1567.

32 Ibid.

33 Printed in Philip Yorke, Earl of Hardwicke, ed., Miscellaneous State Papers From 1501-1726 (London, 1778).

34 Yorke, I, 99.

35 Thomas (1530-1566) was the half-brother of Sir Philip Hoby, the celebrated courtier and diplomat of Henry VIII and Edward VI.

36 Thomas Hoby, A Book of the Travail and Lief of Me Thomas Hoby, ed. E. Powell (London, 1902), pp.36-37.

37 Hoby, pp.36-37.

38 Hoby, pp.53-4, for example.

39 Hoby, p. 19.

40 Hoby, p. 28.

41 Firpo, p.31.

42 Hoby, p.120.

43 Calendar of State Papers, Foreign, Mary, 219.

44 M. St. Clare Byrne and G. Scott Thomson, "My Lord's Books: The Library of Francis, Second Earl of Bedford in 1584," The Review of English Studies, 7 (1931), 385-405.

45 Byrne and Thomson, p.394

46 Public Records Office, SP 69/5, 5 November 1554.

47 Sir John Cheke, The Hurt of Sedition (London, 1549), S.T.C. 5109.

48 Quoted in Parks, "The First ...," 213.

49 English enrolment at the University of Padua continued throughout the century. See I.A. Andrich, De natione anglica et scota iuristarum universitatis patavinae (Padua, 1892), pp. 131-3.

50 L. Firpo, ed., Relazioni di ambasciatori veneti al senato, I, Inghilterra (Torino, 1965), xvii.

51 The oath of orthodoxy was required after 1564. Previously there had been a great deal of religious freedom. See L. Rossetti, L'Università di Padova: Profilo storico (Milan, 1972), p.18; cf. B. Brugi, Gli scolari dello studio di Padova nel Cinquecento (Padova, 1905), p.42: "A Padova mite il vescovo per i tedeschi, di buone maniere l'inquisitore." 